introduced a profound change in the neutrality laws of the United States and enables the President to prevent the shipment of arms or munitions of war, not merely to Mexico, but to any American country wherein conditions of domestic violence unfortunately exist, and which are promoted by the use of arms or munitions of war procured from the United States. The President had, by his proclamation of March $2 \mathrm{~d}$, found that "serious disturbances and forcible resistance to the authorities of the established government exist in certain portions of Mexico." He, therefore, took advantage of the authority conferred upon him by the Joint Resolution of March 14th, which was promptly approved by him, and, on the same day issued the proclamation provided for in the resolution, by declaring and proclaiming formally that "conditions of domestic violence promoted by the use of arms or munitions of war procured from the United States as contemplated by the said Joint Resolution," do in fact exist and he therefore directed all persons to abstain from all violations of the Joint Resolution and warned them that such violations would be rigorously prosecuted. ${ }^{2}$

It is not the purpose of this comment to examine conditions in detail, but to call attention to the importance of the Joint Resolution and to the authority conferred upon the President to prevent export of arms and munitions of war procured in the United States, except under such limitations and exceptions as shall prevent their reaching the revolutionists and their employment for a revolutionary purpose contrary to the neutrality laws of the United States and the Joint Resolution of March 14, 1912. If we can go further and prevent revolutions from being financed in the United States, a great step in advance would be taken to secure domestic peace in the sister republics, without which stable government and ordinary progress would seem to be well-nigh impossible

\title{
THE HORCON RANCH CASE
}

Anent the discussion from time to time arising concerning the inability of the United States Gavernment to perform the international obligations assumed in its treaties, an interesting case arising on the water boundary between the United States and Mexico which has recently been decided by the Circuit Court of the United States in and for the Southern District of Texas affords a refreshing precedent for the vindication

2 Printed in Supplement, p. 147. 
of at least a part, albeit a small part, of the treaty obligations of the United States.

An American company acquired a large tract of land comprising some fifty thousand acres in the southern part of the State of Texas and abutting the Rio Grande River, which river forms the boundary line between the United States and Mexico. The company proposed to develop, cultivate and utilize its lands by the establishment of an extensive system of irrigation and to that end it cleared its lands, built canals, reservoirs, roads, towns, bridges, a complete electrical power station, and constructed on the banks of the Rio Grande River a pumping station in which were installed engines and other mechanical appliances necessary to draw and lift into its canal system from the Rio Grande the water needed for irrigation.

During the progress of this development a natural cut-off in the course of the Rio Grande began to take place, which change if fully accomplished would have caused the river to follow a channel remote from the site which had been selected by the company for its pumping station. It seems that this site, by reason of the natural surroundings, was the only one available for the purpose within several miles and the company was therefore unable to change the site to follow the vagaries of the river.

The company at first attempted to prevent the natural change in the course of the river by revetting the shore at or near the impending cut-off, but the nature of the soil made it practically impossible to do this successfully. The company, thereupon, in order to utilize the extensive works which had been constructed looking to the erection of a pumping station at the point selected, decided to protect itself by cutting an artificial channel further up the stream which would prevent the river from flowing through a loop in which the natural cut-off was threatened. This project of the company was carried to completion during the months of June and July, 1906, in ignorance or in disregard of the treaty provisions between the United States and Mexico, and particularly in direct violation of Article III of the boundary convention between the two governments concluded November 12, 1884, which article reads as follows :

Art. III. No artificial change in the navigable course of the river, by building jetties, piers, or obstructions which may tend to deflect the current or produce deposits of alluvium, or by dredging to deepen another than the original channel under the Treaty when there is more than one channel, or by cutting waterways to shorten the navigable distance, shall be permitted to affect or alter the dividing line as determined by the aforesaid commissions in 1852 or as deter- 
mined by Article I hereof and under the reservation therein contained; but the protection of the banks on either side from erosion by revetments of stone or other material not unduly projecting into the current of the river shall not be deemed an artificial change.

The cut-off not only changed the course of the established and fixed international boundary line, but resulted in injury and damage to the Mexican owners of the lands opposite the point of the diversion in the following particulars: (1) to growing orops; (2) expenses of constructing levees; (3) loss of land from erosion; (4) loss of riparian rights.

The matter was by the Government of Mexico brought to the attention of the International Boundary Commission, which commission by the convention of 1889 has exclusive jurisdiction to examine and decide all differences or questions that may arise on that portion of the frontier where the Ris Grande forms the boundary line, whether such differences or questions grow out of alterations or changes in the bed of the river or of works that may be constructed therein. By the same treaty the commission was given authority to suspend the construction of any works prohibited by Article III of the convention of 1884 , above quoted, pending investigation.

The engineers of the International Boundary Commission investigated the work and found that it had progressed so far as to be beyond control. The commissioners thereupon, after visiting the locality, examining the works, and hearing testimony regarding the case, made the following report to their respective governments:

That the said American Rio Grande Land and Irrigation Company did wrongfully and knowingly cause a change in the current channel of the Rio Grande where it constituted the boundary line between the United States of Mexico and the United States of America, by artificial means, and in direct violation of Article III of the Convention of November 12, 1884, between the two governments, and if said Article III is applied the change in the running channel of the river produces no alteration in the boundary line, which still continues in the old bed of the river.

The Commissioners are of opinion that indemnity should be made for this wrong, but they do not understand that the treaties under which it was organized and under which this investigation was conducted confers upon it jurisdiction over the title to land, damage to property, the control of riparian rights or the enforcing of reparation for wrongs by offenders for changing the channel of the river where it constitutes the boundary.

Nevertheless, as this is a novel case, wherein it appears that some example should be set and a precedent established in order to deter others from similar wrongs, we submit the question to the better judgment of our respective governments for instructions as to further proceedings. 
Upon receipt of the report of the commission by the Department of State of the United States, it was referred to the Attorney-General of the United States, who, under date of May 16, 190\%, replied as follows:

The boundary convention of 1889 with Mexico gives to the International Boundary Commission exclusive jurisdiction to decide the differences and questions growing out of natural or artificial changes in the beds of the Rio Grande and Colorado rivers where they form the boundary line between the United States and Mexico. The authority of the Commission under that treaty is restricted to the determination of questions respecting the boundary alone, and does not extend to the adjudication of private rights and liabilities. The Commission has found here, within its jurisdiction, that the American Rio Grande Land and Irrigation Company, by the construction of its works changing the channel of the river, violated the stipulations of that treaty, which refers to and incorporates the stipulations of earlier treaties.

Both Commissioners huving agreed to this finding or decision, their judgment is binding upon both countries by the express provision of Article VIII of that treaty. Manifestly the Commission is functus officio in this matter, and the question is, how can their decision be carried into effect?

The question of suspending the construction of prohibited works, which is authorized and directed by the treaty, does not arise here, because it appears from the report of the joint engineers that the work had progressed so far as to be beyond control.

As to indemnity for injuries which may have been caused to citizens of Mexico, I am of opinion that existing statutes provide a right of action and a forum. Section 563, Revised Statutes, clause 16, gives to district courts of the United States jurisdiction "of all suits brought by any alien for a tort only in violation of the law of nations or of a treaty of the United States." The act of August 13, 1888, amending and superseding earlier laws (25 Stat,, 433, sec. 1), gives to the circuit courts of the United States "original cognizance, concurrent with the courts of the several States, of all suits of a civil nature at common law or in equity *** in which there shall be, $*^{*}{ }^{*}$ a controversy between citizens of a State and foreign states, citizens, or subjects, in which the matter in dispute exceeds, exclusive of interest and costs, the sum or value aforesaid $[\$ 2,000] . "$

As to the public tort, so to speak - that is, the injury to Mexico in respect to the boundary line by changing the channel of the river-I incline to the view that a treaty of the United States, which is a part of the supreme law of the land, having been violated, a remedy exists to redress that wrong. The United States owes the duty and has the right of vindicating the treaty. It can hardly be doubted that in a proper case calling for prevention the United State may proceed by bill in equity to obtain an injunction, and that in a case like the present, where the prohibited thing has been done, the United States may proceed in the same way to obtain mandatory relief in some appropriate form to compel the restoration of the status quo ante. I find provision for this 
course in the act of 1888, already referred to. That act gives jurisdiction to the circuit courts of the United States of all suits of a civil nature at common law or in equity in which the United States are plaintiffs or petitioners. I am of the opinion that the limitation of jurisdictional amount in that act does not apply to such suits.

The Secretary of State then wrote the Attorney-General:

In reply I have the honor to say that, under all the circumstances, the Secretary of State is of the opinion that it is desirable to institute and maintain a suit against the offending corporation to compel the restoration of the river charnel as it was. The magnitude of the pecuniary interests involved appears to the Secretary of State to be quite unimportant as compared with the observance of good faith on the part of the United States and the public evidence that will be given of the purpose of the Government to insist upon the observance by citizens of the United States of the treaty with Mexico as a part of the supreme law of the land.

Accordingly the Department of Justice, through the United States Attorney for the Southern District of Texas, filed a bill in equity against the irrigation company, setting forth the above facts, in which it alleged that the action of the company was a violation of the provisions of the treaties above referred to and contrary to the statutes and to international law, and "that such wrongful and unlawful diversion and change in the channel of said Rio Grande by defendant, aforesaid, forming as it then did the natural boundary line between the two said countries, established and fixed by treaty, even though the boundary itself be not thereby changed, constitutes an act in contempt and in violation of the sovereign authority and power of the two said governments." The bill further alleged:

That by virtue of the terms and effect of existing treaties the two said governments, and particularly the Government of the United States of America, complainant, became obligated, and all persons, corporations and inhabitants within its territorial limits, particularly the American Rio Grande Land and Irrigation Company, defendant, became similarly obligated, to vindicate, maintain, and continue in full force and effect each and every provision, duty, obligation and requirement set out or implied in the said existing treaties. That by the force and effect of law and the said treaties, complainant, the United States of America, and the said defendant became especially obligated to recognize and maintain the Rio Grande as the boundary line between the two countries, as in the treaties declared.

The bill then prayed that "In recognition of the obligations and duties imposed upon complainant, the United States of America, by its treaties with the United States of Mexico, and particularly its obligation 
to maintain the fixed international boundary lines $* * *$ in its natural course and position, and because of its wrongful and unlawful change and diversion in the course and current of the entire flow of the water of said river by said defendant company," the court compel the defendant to restore the river to its original bed and to make restoration of the status quo ante in all other particulars as nearly as possible as it existed at or before the time of the diversion of the river. The bill further prayed that, if it should appear to be practically impossible to make such restoration, then the court should decree in the alternative that the defendant: (1) convey to the owners of the Mexican lands which had been damaged, all the land belonging to the defendant that was "cut off" or cast upon the southern banks of the Rio Grande by the diversion; (2) pay to the owners of the Mexican lands a sum to cover the damages sustained by them; (3) reimburse the United States for the costs and expenses incident to surveying and marking the international boundary line represented by the former bed of the Rio Grande before the diversion; and (4) pay to the United States a further sum as a penalty for violating the provisions of the treaties.

The irrigation company confessed judgment upon the bill, but pleaded that it had become impossible to restore the Rio Grande to its original bed and prayed the court to decree the alternative relief asked in the bill.

The case was heard upon bill and answer and the alternative relief granted by the following decree dated December 5, 1911:

\section{DECREE}

IN THE CIRCUIT COURT OF THE UNITED STA'TES, IN AND FOR THE SOUTHERN DISTRIOT OF TEXAS, BROWNSVILLE DIVISION.

In Equity. No. 41.

The United States, et ALs., Complainants,

vs.

The amerioan Rio Grande land \& Irigation Compant, Defondant

On this 5th day of December, 1911, at Brownsville, Texas, in said district, in open court, being a day of the regular term of said court, came the United States of America, complainant, by its attorney, Lock McDaniel, for said Southern District, and its co-complainant, Señor Don Adelberto A. Arguelles, Trustee, by his attorney, R. E. Holland, and the American Rio Grande Land \& Irrigation Company, defendant, by its attorney, DuVal West, Esq., and submitted said cause for hearing upon the complainants' bill and defendant's answer.

Upon due consideration thereof, it is ordered, adjudged, and decreed: 
First. - That defendant, American Rio Grande Land \& Irrigation Company, do convey to the complainant, Señor Don Adelberto A. Arguelles, Trustee, by warranty desd, for the benefit of all of the owners of lands situated in Mexico damaged by the unlawful diversion of the Rio Grande, all that tract or parcel of land belonging to said defendant company that was "cut-off" or cast upon the southern bank of the Rio Grande by said unlawful diversion, being situated in Hidalgo County, Texas, forming part of the Llano Grande grant of land and the Capisallo Land District, containing 246.56 acres, more or less, particularly described as follows:

Survey begins at a mesquite post marked "K," on the South bank of the Rio Grande, and near what was the West Bank of that River before the cut-off was made; said mesquite post lying in the Eastern portion, in the north extreme eastern portion of said Banco. Said post is connected with the Capisallo base line of said American Rio Grande Land \& Irrigation Company by the following courses and distances:

Beginning at a froint on said base line $1,405.93 \mathrm{ft}$. north of zero of the zero point, thence following the meanders of the North bank of the Rio Grande River by the courses and bearings, N. 78 de. $05^{\prime}$ E. 826.09 ft. N. 67 de. $391 / 2^{\prime}$ E. 2099.58 ft. N. 63 de. $4811^{\prime}$ E. 1305.24 ft. N. 68 de. $04^{\prime}$ E. 1492.64 ft. N. 70 de. $191 / 2^{\prime \prime}$ E. 1478.22 ft. N. 77 de. $131 / 2^{\prime}$ E. 322.80 ft. S. 81 de. $1814^{\prime}$ E. $1037.90 \mathrm{ft}$. S. 46 de. $071 / 4^{\prime}$ F. 1206.52 ft. S. 83 de. $101 / 2^{\prime}$ E. 325.06 ft. S. 4 de. $14^{\prime}$ W. $520.71 \mathrm{ft}$. thus establishing the position of the mesquite post above described.

Now starting from said mesquite post as the point of beginning, and follow. ing the meanders of the old river bed the said Bank is bounded as follows:

South 30 de. $55^{\prime}$ W. 1878.55 ft. S. 44 degrees $40^{\prime}$ W. $717.00 \mathrm{ft}$. S. 56 de. $201 / 2^{\prime}$ W. 845.74 ft. S. 64 de. $321 / 2^{\prime}$ W. 551.43 ft. S. 77 de. $35^{3 / 4^{\prime}}$ W. 1600.01 ft. S. 77 de. $29^{\prime}$ W. 1699.99 ft. $S .77$ de. $311^{\prime} 4^{\prime}$ W. 815.60 ft. N. 75 de. $02^{\prime}$ W. $588.68 \mathrm{ft}$. N. 5 de. $0534^{\prime}$ W. 1618.90 ft. N. 37 de. $231 / 4^{\prime}$ E. 911.47 ft. N. 78 de. $06^{1 / 4^{\prime}}$ E. $604.48 \mathrm{ft}$. S. 57 de. $19^{\prime}$ E. 606.84 ft. S. 43 de. $55^{\prime}$ E. $551.37 \mathrm{ft}$. S. 35 de. $09^{\prime}$ E. 604.81 ft. N. 84 de. $22^{\prime}$ E. 833.84 ft. S. 83 de. $223 /^{\prime}$ E. 193.15 ft. N. 73 de. $3834^{\prime}$ E. 857.92 ft. N. 45 de. $331 / 2^{\prime}$ E. 673.11 ft. N. 52 de. $0 l^{\prime}$ E. $1355.12 \mathrm{ft}$. N. 27 de. $02^{\prime}$ E. $529.09 \mathrm{ft}$. N. 9 de. $011 / 2^{\prime}$ E. $705.50 \mathrm{ft}$; to a point at the most northern point of this Banco on the southern bank of the said Rio Grande River. Thence with the meanders of the Rio Grande S. 61 de. $5834^{\prime}$ E. $437.98 \mathrm{ft}$. S. 67 de. $10 \frac{1}{4^{\prime}}$ E. $302.18 \mathrm{ft}$. S. 77 de. $57^{\prime}$ E. $618.80 \mathrm{ft}$. to the place of beginning, containing in all 246.570 acres of land more or less.

All that portion of the land lying between the approximate said line of the old river hed as shown by the polygon NOPQRSTUVWXY, and the circuit lines of the Banco above described and containing in all one hundred and twenty (120) acres of land more or less, making an aggregate total of 1366.57 acres.

Second. - That defendant, the American Rio Grande Land \& Irrigation Com. pany do pay unto the complainant, Señor Don Adelberto A. Arguelles, Trustee, Five Thousand Dollars for the benefit of all the owners of Mexican lands so damaged, and particularly for the benefit of: Lic. Joaquin Arguelles, Lic. Jose Arguelles, Senorita Consuelo Arguelles, Don Manuel Cantu and Senores Desiderio Cantu, Ignacio Cantu, Emilio Zamora, Felicitas Garcia, Primitivo Hinojosa, Reducindo Olivares, Geronimo Bazan, Ignacio Castaneda, Jorge Cantu, Julian 
Cantu, Natividad Cantu, Jose Angel Hernandez, Santos Cantu, Baltazar Lopes, and the Senoras Manuela Garza Viuda de Cantu, Petra Cisneros Viuda de Hinojosa, Francisca Fraustra Viuda de Bazan, Antonio Rodriguez Viuda de Cantu, and Antonio Garza Viuda de Hernandez. And that the said conveyance of said land and the said payment of said Five Thousand Dollars shall be and constitute a full liquidation and settlement of all damages occasioned to all of the owners of Mexican lands damaged by the unlawful acts of defendant, American Rio Grande Land \& Irrigation Company.

Third.-- That defendant, American Rio Grande Land \& Irrigation Company, do pay to the United States of Ameriea, Complainants, the sum of Two Thousand $(\$ 2,000)$ Dollars to cover costs and expenses incident to surveying and marking the international boundary line now represented by the former bed or channel of the Rio Grande before the unlawful diversion of the stream was made by defendant, as aforesaid.

Fourth. - That as a penalty for violating the provision of the treaties, as aforesaid, in making, by artificial means, the unlawful change, diversion and interference with the natural channel, course and flow of the waters of the international boundary line stream, the Rio Grande, by reason of the wrongful acts complained of, that the defendant company pay to complainant, the United States of America, the sum of Ten Thousand $(\$ 10,000)$ Dollars and court costs in the sum of Two Hundred (\$200) Dollars.

W. T. BurNs, Judge.

\section{THE USE OF BALLOONS IN THE WAR BETWEEN ITALY AND TURKEY}

In a newspaper dispatch of March 21st, it is stated that the Italian forces have been dropping explosives from dirigible balloons upon Turkish forces, and that a bomb was dropped from a balloon over the town of Zanzour some fourteen miles west of the city of Tripoli; that the bomb fell into the street, killing four persons and wounding ten others, all of them noncombatants.

This item, whether true or not, calls attention to the possible use of balloons in warfare, and has given rise to a discussion whether the Italian forces are justified in dropping explosives from balloons. Whether balloons should be used in the prosecution of hostilities is a question which will not be discussed at present. The following paragraphs will be devoted to a brief examination of the law involved and the applicability of the Declaration, adopted by the First Hague Conference and renewed by the Second, forbidding the dropping of explosives from balloons. The First Hague Conference adopted the following declaration: "The contracting Powers agree to prohibit, for a period 